\title{
THERMAL DECOMPOSITION OF TORREFIED AND CARBONIZED BRIQUETTES OF RESIDUES FROM COFFEE GRAIN PROCESSING
}

\author{
Decomposição térmica de briquetes torrificados e carbonizados de \\ resíduos do processamento dos grãos de café
}

\author{
Thiago de Paula Protásioํㅗ Isabel Cristina Nogueira Alves de Melo², Mario Guimarães Junior ${ }^{3}$, \\ Rafael Farinassi Mendes 2 , Paulo Fernando Trugilho ${ }^{2}$
}

\begin{abstract}
The use of biomass has been recognized as a potential renewable energy and an alternative substitute that contributes to the decrease of fossil fuels consumption. Therefore, this research aimed to analyze the thermal behavior of briquettes made of residues from coffee grain processing in different conditions: in natura, torrefied and carbonized. Eucalyptus sawdust was used for comparison. The briquettes were carbonized considering final temperature of $450^{\circ} \mathrm{C}$ (kept for $30 \mathrm{~min}$ ). The briquettes torrefaction was performed in an electric oven (muffle) using two heating rates until $250^{\circ} \mathrm{C}$ (kept $60 \mathrm{~min}$ ). The thermal-gravimetric analysis was made in nitrogen atmosphere until the temperature of $600^{\circ} \mathrm{C}$. The contents of fixed carbon and volatile matter of the fuels were determined. The carbonized briquette of residues from coffee grain processing presented higher stability and low thermal decomposition. It was observed a low influence of torrefaction heating rate under thermal properties of briquettes, and fixed carbon and volatile matter content. Regarding the raw biomass, lower total mass loss was observed for the residues from coffee grain processing when compared to Eucalyptus sawdust. The carbonized and torrefied briquettes presented higher hydrophobicity than raw briquettes.
\end{abstract}

Index-terms: Solid biofuels, residual biomass, coffee plantations, stability.

\section{RESUMO}

O uso da biomassa tem sido reconhecido como uma energia potencial renovável e um substituto alternativo que contribua para a redução do consumo de combustíveis fósseis. Portanto, objetivou-se analisar o comportamento térmico de briquetes de resíduos do processamento dos grãos de café, em diferentes formas: in natura, torrificados e carbonizados. Utilizou-se a serragem de Eucalyptus como parâmetro de comparação. Os briquetes foram carbonizados considerando a temperatura final de $450^{\circ} \mathrm{C}$ (mantida por $30 \mathrm{~min}$ ). A torrefação dos briquetes foi realizada em uma mufla em duas taxas de aquecimento até $250^{\circ} \mathrm{C}$ (mantida por 60 min). Realizou-se a análise termogravimétrica em atmosfera de nitrogênio até a temperatura de $600^{\circ} \mathrm{C}$. Determinaram-se os teores de carbono fixo e materiais voláteis dos combustíveis. O briquete carbonizado dos resíduos do processamento dos grãos de café apresentou a maior estabilidade e baixa decomposição térmica. Observou-se baixa influência da taxa de aquecimento de torrefação nas propriedades térmicas dos briquetes e nos teores de carbono fixo e materiais voláteis. Quanto às biomassas in natura observou-se menor perda de massa total para os resíduos do processamento dos grãos de café em comparação a serragem de eucalipto. Os briquetes carbonizados e torrificados apresentaram caráter mais hidrofóbico em relação ao briquete in natura.

Termos para indexação: Biocombustíveis sólidos, biomassa residual, cafeicultura, estabilidade.

(Received in december 6, 2012 and approved in march 3, 2013)

\section{INTRODUCTION}

The use of biomass has been recognized as a potential renewable energy and an alternative substitute that contributes to the decrease of fossil fuels consumption (SHEN; GU, 2009; KIM; EOM; WADA, 2010; PROTÁSIO et al., 2013). In this context, Brazil has advanced in relation to the use of clean renewable energy due to its potential on agricultural and forest cultures. Almost $46 \%$ of Brazilian energetic matrix is derived from renewable resources, $14 \%$ corresponding to hydropower and $32 \%$ related to several types of biomass and other renewable energies (BRASIL, 2011).

Among agricultural residues, the bark and parchment of coffee derived from the fruit processing may be highlighted as a raw material of high energetic potential, since it is produced in large scale in Brazil, the largest coffee producer of the world; in 2012 this country must harvest from 48.97 to 52.27 millions of bags of processed coffee (COMPANHIA NACIONAL DE ABASTECIMENTO-CONAB, 2012). Moreover, this

${ }^{1}$ Universidade Federal de Lavras/UFLA - Departamento de Ciências Florestais/DCF - Cx. P. 3037 - $37200-000$ - Lavras - MG - Brasil depaulaprotasio@gmail.com

${ }^{2}$ Universidade Federal de Lavras/UFLA - Departamento de Ciências Florestais/DCF - Lavras - MG - Brasil

${ }^{3}$ Centro Federal Educação Tecnológica de Minas Gerais/CEFET-MG - Departamento de Eletrônica - Araxá - MG - Brasil 
lignocellulosic residue presents chemical, physical and energetic characteristics favorable to the production of bioenergy through thermochemical processes (PAULA et al., 2011a; PAULA et al., 2011b; PROTÁSIO et al., 2011a; PROTÁSIO et al., 2011b; PROTÁSIO et al., 2012a; PROTÁSIO et al., 2012b).

This way, the residues generated by this process consist of an attractive alternative source of energy, but firstly it is necessary to improve techniques in order to solve some limitations in relation to the use of biomass in natura, like the high content of moisture, low energetic density (PROTÁSIO et al., 2011a), hygroscopic behavior, difficulties on storing and transporting.

Chen and Kuo (2011) suggests that some of these problems may be reduced through thermal pre-treatment of biomass, and the torrefaction is one of the methods liable to be applied. In this process the biomass in natura is heated to $225-300^{\circ} \mathrm{C}$ (PRINS; PTASINSKI; JANSSEN, 2006).

Some results found on literature confirm the efficiency of torrefaction is one of the methods liable to be applied on the improvement of some properties of biomass, like the increase of energetic density (FELFLI et al. 2005; PRINS; PTASINSKI; JANSSEN, 2006; COUHERT, SALVADOR; COMMADRÉ, 2009; YAN et al., 2009) and the proportion $\mathrm{C} / \mathrm{O}$, which results in the increase of fuel energetic value (BRIDGEMAN et al., 2008; COUHERT, SALVADOR; COMMADRÉ, 2009; YAN et al., 2009; PROTÁSIO et al., 2012a), inversion of the characteristic hygroscopic behavior for hydrophobic (DENG et al., 2009; PROTÁSIO et al., 2012a), such the torrefied fuel presents low moisture content and facility to be stored, besides significant improvement of inflammability, reactivity and milling (ARIAS et al., 2008; BRIDGEMAN et al., 2008; REPELLIN et al., 2010).

In this sense, the use of thermal analyses plays an important role on evaluating the performance of lignocellulosic material to be used on thermochemical processes. The thermal-gravimetric analysis (TGA) is an important tool on identifying degradation phases of biomass constituents and, consequently, for the analysis of torrefaction and carbonization efficiency.

Therefore, the objective of this work was to analyze the thermal behavior of briquettes made of residues from coffee grains processed in natura, torrefied and carbonized. Sawdust of Eucalyptus was used for comparisons.

\section{MATERIAL AND METHODS}

In order to produce the briquettes, residues from coffee (Coffea arabica L.) grain processing, bark and parchment of the variety Icatu IAC 3282 from EPAMIG experimental farm in the municipality of Machado, Minas Gerais state $\left(21^{\circ} 40^{\prime} 42,54^{\prime \prime} \mathrm{S} 45^{\circ} 56^{\prime} 31,38^{\prime \prime} \mathrm{W}\right)$ were used. The plantation was established on 1995.

The biomass was ground in hammer mill, in which a sieve $2 \mathrm{~mm}$ mesh was linked for granulometric reduction. It was posteriorly classified in sieves 40, 60 and 270 mesh. Compressed residual biomass contained $84 \%$ of particles with diameter longer or equal to $0.425 \mathrm{~mm}, 11 \%$ with diameter between $0.425 \mathrm{~mm}$ and $0.250 \mathrm{~mm}$, and $5 \%$ with diameter shorter than $0.250 \mathrm{~mm}$.

Compressing of residues was made in a hydraulic briquetter Lippel ${ }^{\circledR}$, model LB 32. The biomass was previously dried at $103 \pm 2^{\circ} \mathrm{C}$. The temperature used for compressing was $120 \pm 5^{\circ} \mathrm{C}$ and pressure equal to $15 \mathrm{MPa}$. Briquettes were produced with diameter of approximately $3 \mathrm{~cm}$ and 6 to $7 \mathrm{~cm}$ high (PAULA et al., 2011a; PROTÁSIO et al., 2011a).

Carbonization of briquettes was performed in an electric stove (muffle), using a heating rate of $1.67^{\circ} \mathrm{C} \mathrm{min}$. Initial temperature was $50^{\circ} \mathrm{C}$ and final temperature was $450^{\circ} \mathrm{C}$, kept during $30 \mathrm{~min}$. Total carbonization lasted $4.5 \mathrm{~h}$.

Briquettes torrefaction at muffle was made with two distinct heating rates, the first of $1.5^{\circ} \mathrm{C} \mathrm{min}^{-1}$ (rate 1) and the second of $3.0^{\circ} \mathrm{C} \mathrm{min}^{-1}$ (rate 2), both with final temperature of $250^{\circ} \mathrm{C}$ kept during 60 minutes.

All analyses were performed for briquettes in natura (control briquette), as well as for thermally treated briquettes. Eucalyptus sawdust was used as parameter for comparison, which came from sawing of logs, once this wood is widely used for energy generation or, in the case of residues, for co-generation. Samples compounded by 6 repetitions for each treatment, in natura, torrefied and carbonized material were used for thermal-gravimetric analysis (TGA).

For TGA, the fuels of vegetal biomass were grounded to powder using the granulometric fraction that passed through the sieve 200 mesh and was retained by the sieve 270 mesh. The equipment DTG-60H SHIMADZU was used for this analysis. Samples of approximately $4 \mathrm{mg}$ were submitted to a temperature gradient ranging from environment temperature to $600^{\circ} \mathrm{C}$ with heating rate of 10

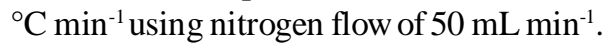

Using the first derivative of TG curve which establishes the mass loss in function of temperature, it was possible to identify the rate of mass loss by second and the characteristic peaks of biomass thermal degradation.

The immediate chemical analysis of biomass fuels was made in order to quantify the content of volatile matter and ashes, and by difference, the fixed carbon according 
to ASTM D1762-84 standard (AMERICAN SOCIETYFOR TESTING MATERIALS-ASTM, 2007). Analysis of variance (ANOVA) were performed considering one entirely randomized design with 5 treatments (carbonized briquette, torrefied briquette in rate 1 , torrefied briquette in rate 2, in natura briquette and Eucalyptus sawdust) and 4 repetitions. Mean were compared statistically by Tukey test at $5 \%$ of significance.

\section{RESULTS AND DISCUSSION}

Mass loss in function of temperature (TG curve) of the analyzed fuels is shown on figure 1. It is possible to observe that carbonized briquettes obtained the highest thermal stability, thus presenting high resistance to thermal degradation.

Torrefied briquettes presented intermediate position. This result may be attributed to thermal treatment applied to briquettes which resulted on degradation of molecular components and consequently on carbon fixation.

In this case, it is possible to affirm that, during thermal treatment (torrefaction), endothermal reactions with release of water, acetic acid, methanol, carbon dioxide and other oxygenated gases predominated, which molecules came from thermal decomposition of hemicelluloses (PRINS; PTASINKSKI; JASSEN, 2006), thus resulting on carbon fixation (Figure 2). The greater thermal decomposition of hemicelluloses is due to their amorphous and easily hydrolysable chemical structure (YANG et al., 2006; JOHN; THOMAS, 2008).

Fuels with higher contents of fixed carbon and low volatile matter tend to burn slowly (BRAND, 2010), because fixed carbon represents the fraction of fuel that burns on solid state, justifying the results observed on Figures 1 and 2. The reduction of the relation oxygen/carbon on fuels also provided an increase on resistance to thermal degradation, which is one of the objectives of torrefaction and carbonization processes (CHEN et al., 2011).

Regarding in natura biomass, it was observed that residues of coffee grain processing (control briquette), even starting thermal decomposition early, they presented higher resistance to thermal degradation and lower mass loss rate when compared to Eucalyptus sawdust (Figure 1).

Biomass volatilization and consequently thermal degradation depends on its chemical composition, as well as cellulose and lignin content (GANI; NARUSE, 2007). Protásio et al. (2012b) observed high content of insoluble lignin $(31.03 \%)$ for bark and parchment of coffee grain, overcoming other lignocellulosic residues from agricultural and forestry activities, including Eucalyptus residual wood $(25.65 \%)$.

The results found by Protásio et al. (2012b) corroborate with tendencies observed in this work, because among molecular chemical contents, lignin presented the

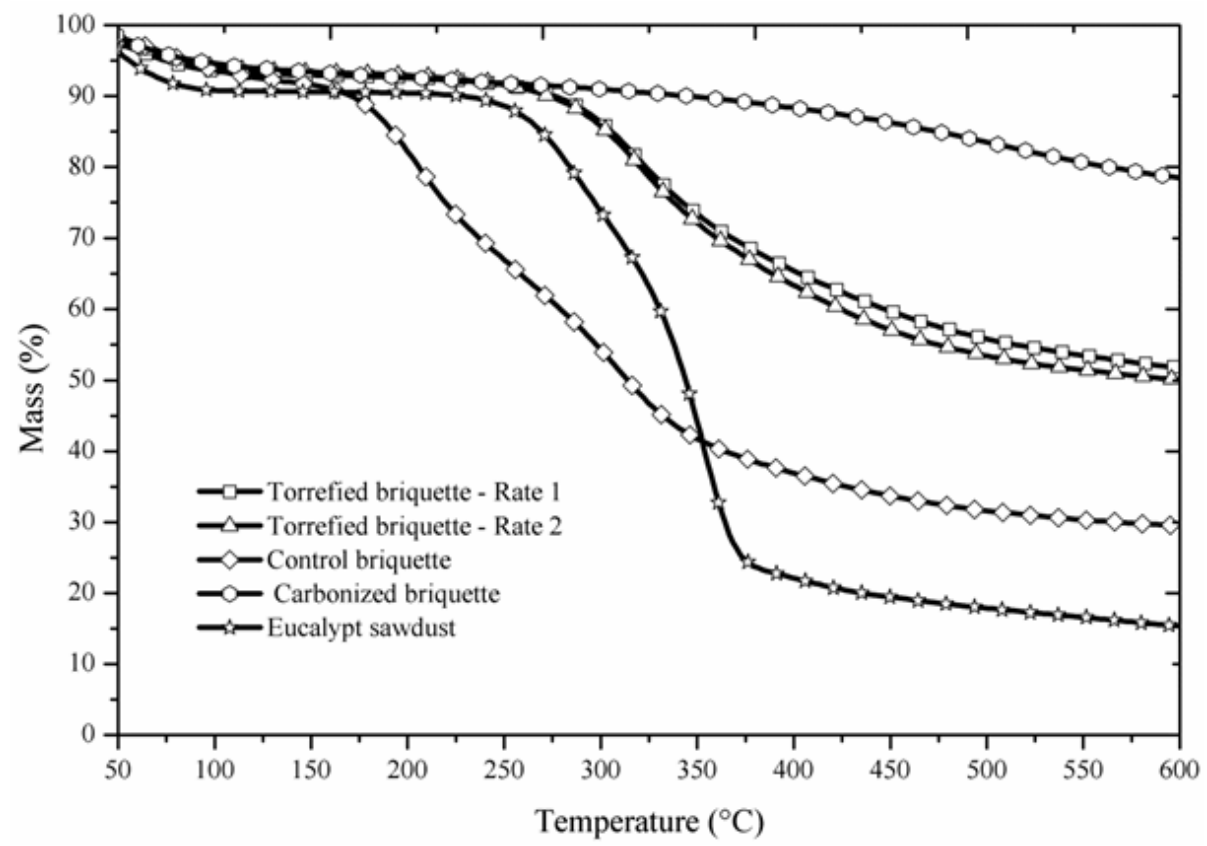

Figure 1 - Mass loss in function of temperature of the analyzed fuels. 
highest thermal stability due to carbon-carbon bonds among monomeric units of phenyl-propane and consequently the stability of its aromatic matrix, besides presenting high molecular weight (SHAFIZADEH, 1985; BARTKOWIAK; ZAKRZEWSKI, 2004; SHARMA et al., 2004; YANG et al., 2006; GANI; NARUSE, 2007; JOHN; THOMAS, 2008).

There are reports on the literature related to the increase of carbon content and consequently the reduction of volatile matter content as final pyrolysis temperature increases (DEMIRBAS, 2001; TRUGILHO; SILVA, 2001; DEMIRBAS, 2004), resembling to the observed in the present work (Figure 2).

It is possible to note that carbonized briquette presented higher mean value of fixed carbon and lower volatile matter content. Torrified briquettes at rate 1 and 2 presented similar and intermediate immediate chemical composition, and consequently the total mass loss also was similar. This result is an indicative of the low influence of heating rate used during torrefaction process on chemical and thermal properties of such fuels.

The briquette made of residues from coffee grain processing (control briquette) presented approximately $71 \%$ more fixed carbon than Eucalyptus sawdust, justifying the lower total mass loss (Figures 1 and 2). This result may be attributed to the higher lignin content of residues from coffee grain processing, as reported by Protásio et al. (2012b)

Lignin contains higher carbon content than other chemical components. Thus, it is expected that the higher the lignin content, higher fixed carbon content of fuels (BARTKOWIAK; ZAKRZEWSKI, 2004; GANI; NARUSE, 2007), reinforcing the found tendencies (Figure 2).

Eucalyptus sawdust lost $20 \%$ more mass, considering final temperature of $600^{\circ} \mathrm{C}$. Despite it is commonly used on energy generation, directly in boilers or on briquettes production (PAULA et al., 2011a; PROTÁSIO et al., 2011a), residues from sawing of Eucalyptus logs (sawdust) tend to burn faster, as can be observed on figures 1 and 2.

This result shows the potential of energetic use of bark and parchment of coffee grain, not only because of the high Brazilian production of this grain (CONAB, 2012), but also because of chemical, physical, energetic and thermal characteristics of this residue (PAULA et al., 2011a; PAULA et al., 2011b; PROTÁSIO et al., 2011a; PROTÁSIO et al., 2011b; PROTÁSIO et al., 2012a; PROTÁSIO et al., 2012b).

Analysing DTG curves (Figure 3), it is possible to note that in natura biomass presented three distinct stages of thermal degradation, it means, three peaks of mass loss.

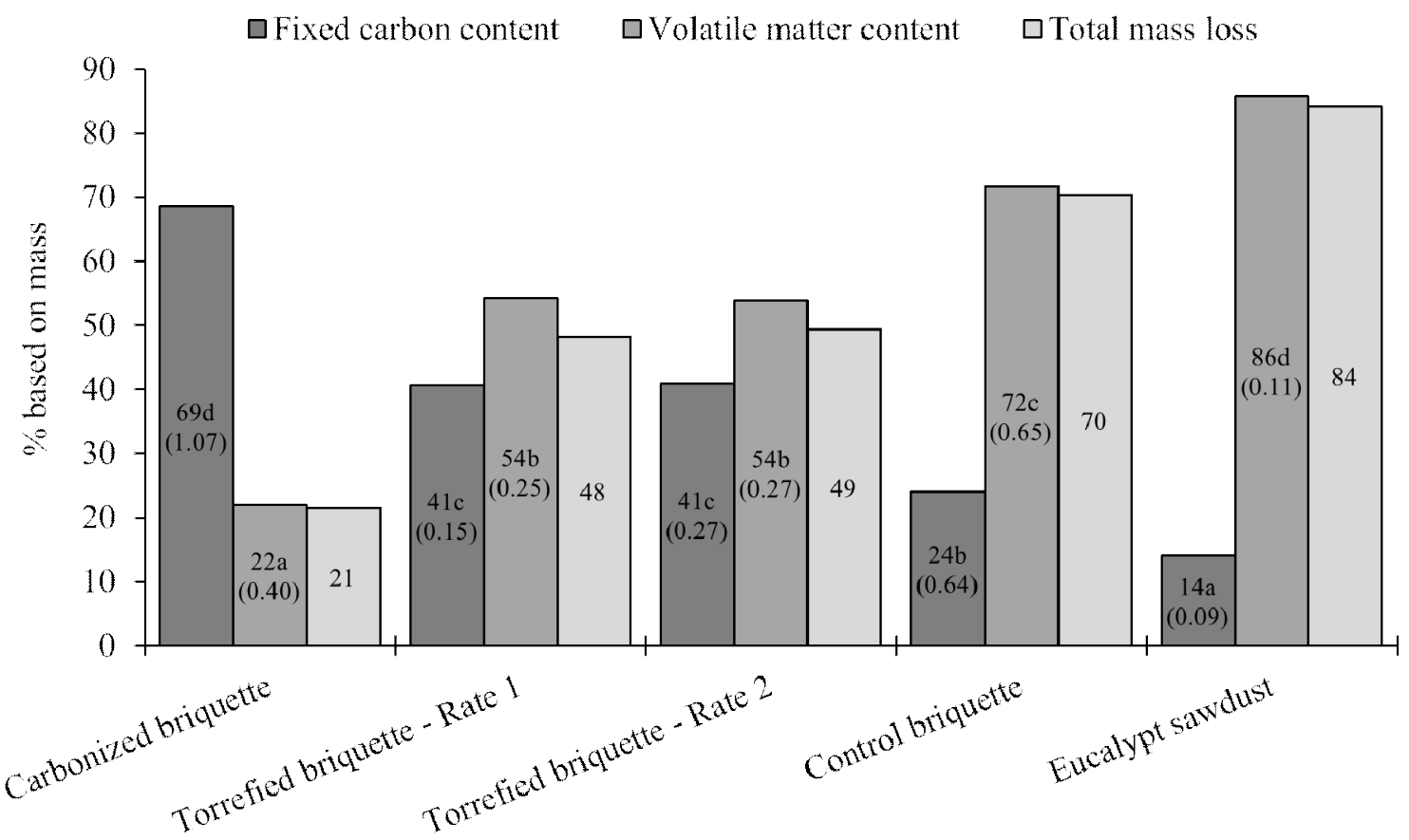

Figure 2 - Fixed carbon, volatile matter and total mass loss. Means followed by the same letter do not differ among themselves at $5 \%$ of significance by Tukey Test. Standard deviation in parentheses.

Ciênc. agrotec., Lavras, v. 37, n. 3, p. 221-228, maio/jun., 2013 


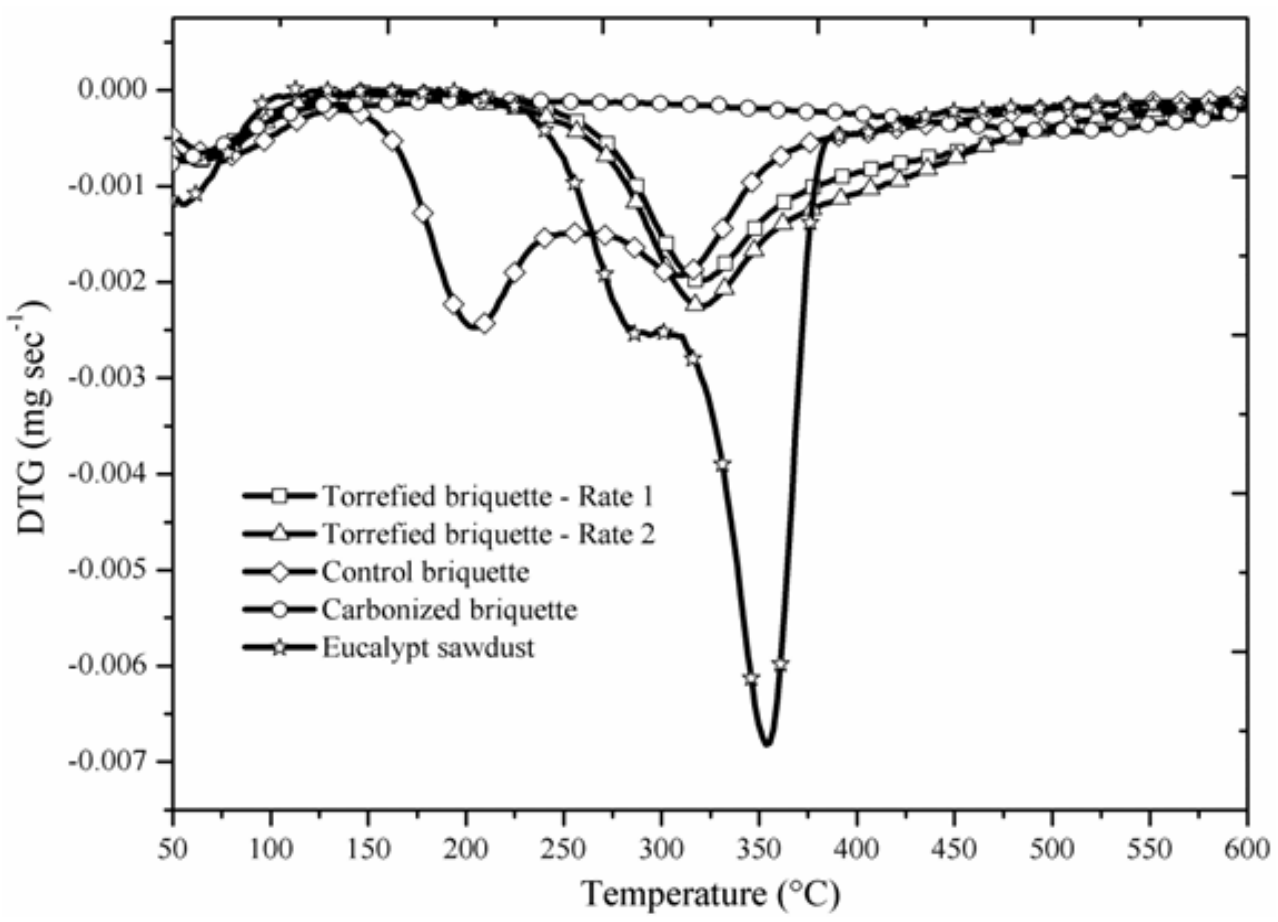

Figure 3 - DTG curves of analyzed fuels.

Thermally treated briquettes (torrefied and carbonized) presented only two stages of thermal degradation, suggesting the efficiency of thermal treatment performed.

The formation of a slight shoulder on DTG curve of Eucalyptus sawdust (Figure 3) is an indicative of hemicelluloses degradation, as reported by Polleto et al. (2012). The authors observed a characteristic peak of degradation of hemicelluloses present on the wood of four species in approximately $300^{\circ} \mathrm{C}$, resembling to the observed in this work $\left(288.9^{\circ} \mathrm{C}\right)$.

Hemicelluloses are degraded between $180^{\circ} \mathrm{C}$ and $350^{\circ} \mathrm{C}$ (KIM et al., 2006), cellulose between $305^{\circ} \mathrm{C}$ and $375^{\circ} \mathrm{C}$ (SHAFIZADEH, 1985) and lignin between 250 and $500^{\circ} \mathrm{C}$ (SHAFIZADEH, 1985; KIM et al., 2006). Therefore, during the torrefaction processes, part of the content of cellulose and lignin are preserved, justifying the presence of two typical stages of degradation.

Analyzing stage I (Table 1), relative to sample water loss, it is possible to note that Eucalyptus sawdust presented higher moisture in relation to the other analyzed fuels. This may be attributed to the higher hemicelluloses content, because these molecular components are the main responsible by the water absorption due to its amorphous and branched character (PRINS; PTASINKSKI; JASSEN, 2006).
In relation to fuels submitted to thermal treatment of torrefaction and carbonization, a reduction of moisture is observed (I degradation stage) (Table 1), it means, an increase of briquettes hydrophobicity occurred, what is a great advantage since water decreases considerably the caloric value of the biomass fuels. It is known that latent heat of water is approximately $2.32 \mathrm{MJkg}^{-1}$ (BRAND, 2010).

Eucalyptus sawdust lost $50 \%$ of mass at a temperature superior $\left(345^{\circ} \mathrm{C}\right)$ to residues of coffee grain processing $\left(313^{\circ} \mathrm{C}\right)$ (Figure 1$)$, it means, forestry biomass presented thermal degradation at temperatures superior to the analyzed agricultural residue, as may be observed at the higher values obtained for onset, endset and peak temperature at stages II (in which occurs mainly degradation of hemicelluloses) and III (in which occurs only degradation of remaining hemicelluloses and celluloses). This shows that the torrefaction of briquettes from Eucalyptus sawdust may be technically viable resulting on high gravimetric yield in torrefied briquettes, once torrefaction is made between the temperatures $225^{\circ} \mathrm{C}$ and $300^{\circ} \mathrm{C}$ (PRINS et al., 2006).

The presence of high extractive content (components of low molecular weight) on residues of coffee grain processing (PROTÁSIO et al., 2012b) may promote the biomass inflammability at lower temperatures due to 
Table 1 - Onset temperature $\left(\mathrm{Ton}-{ }^{\circ} \mathrm{C}\right)$, endset temperature $\left(\mathrm{Tend}-{ }^{\circ} \mathrm{C}\right)$, maximum degradation temperature $\left(\mathrm{Tp}-{ }^{\circ} \mathrm{C}\right)$ and percentage of mass loss $(\mathrm{P} \%)$

\begin{tabular}{ccccccccccccc}
\hline \multirow{2}{*}{ Fuel } & \multicolumn{3}{c}{ Degradation Stage I } & \multicolumn{4}{c}{ Degradation Stage II } & \multicolumn{4}{c}{ Degradation Stage III } \\
& Ton & Tend & Tp & P\% & Ton & Tend & Tp & P\% & Ton & Tend & Tp & P\% \\
\hline BWT & 54.0 & 101.7 & 73.9 & 7.9 & 185.6 & 216.2 & 203.4 & 27.5 & 296.7 & 362.4 & 310.4 & 34.9 \\
ES & 44.7 & 46.1 & 45.3 & 9.3 & 269.5 & 290.1 & 288.9 & 12.8 & 335.1 & 376.4 & 354.2 & 62.1 \\
\hline BT1.5 & 44.7 & 88.1 & 56.3 & 7.0 & 282.9 & 406.0 & 318.6 & 41.0 & - & - & - & - \\
BT3.0 & 49.5 & 94.8 & 66.1 & 6.3 & 281.2 & 407.0 & 320.3 & 43.0 & - & - & - & - \\
CB & 45.7 & 90.1 & 48.6 & 6.6 & 439.5 & 573.0 & 506.5 & 14.8 & - & - & - & - \\
\hline
\end{tabular}

BWT: briquette made of residues of coffee grain processing without thermal treatment; ES: Eucalyptus sawdust; BT1.5: briquette torrefied at $1.5^{\circ} \mathrm{C} \min ^{-1}$; BT3.0: briquette torrefied at $3.0^{\circ} \mathrm{C} \mathrm{min}^{-1} ; \mathrm{CB}$ : carbonized briquette.

the higher volatility and then improve the process of thermal degradation (GRØNLI; VÁRHEGYI; DI BLASI, 2002; SHEBANI; VAN REENEN; MEINCKEN, 2008; POLLETO et al., 2012), what would justify the lower values for onset, endset and peak temperatures at stages II and III when compared to Eucalyptus sawdust (Table 1).

However, the mass loss of Eucalyptus sawdust at stage III was $78 \%$ superior to in natura briquette (Table 1), what may be attributed to the intense cellulose degradation (SHAFIZADEH, 1985; POLLETO et al., 2012), showing that carbonization of briquettes made of this forestry residue will result on low yield and high production of pyroligneous liquid and not condensable gases.

Polleto et al. (2012) also observed intense cellulose degradation at $350^{\circ} \mathrm{C}$ studying the wood of four species, resembling to the observed in this work for Eucalyptus sawdust $\left(354^{\circ} \mathrm{C}\right)$. Cellulose molecule is a long polymer formed by several glucose monomers and its crystalline regions improves the thermal stability, providing higher degradation temperature in relation to hemicelluloses (YANG et al., 2006).

Considering stage II, it is observed that thermal degradation of torrefied and carbonized briquettes started later in relation to in natura briquette. According to Liu et al. (2007) and Morán et al. (2008), the increase of crystalline component causes the increase of thermal stability of the sample, allowing thermal degradation to start later, as observed in this work.

It is also observed the similarity of onset, endset and peak temperature for torrefied briquettes, as well as the mass loss (Tables 1 and 2), suggesting that the heating rate of the stove had a weak influence on thermal properties of briquettes.

Carbonized briquette presented the highest maximum degradation temperature $\left(506^{\circ} \mathrm{C}\right)$, once the pyrolysis final temperature to which it was submitted $\left(450^{\circ} \mathrm{C}\right)$ provided the total degradation of hemicelluloses and cellulose, as well as lignin, modifying them thermally. This may be seen through the analysis of TG and DTG of in natura curve, which tends to stabilize and lacks peaks of intense thermal degradation from $376^{\circ} \mathrm{C}$ on, it means, from this temperature on, the biomass loss is basically attributed to the presence of residual lignin.

Therefore, the process of carbonization provided a hydrophobic character to the briquette made of residues of coffee grain processing, besides improving considerably its resistance to thermal degradation.

\section{CONCLUSIONS}

Carbonized briquette made of residues of coffee grain processing presented the highest stability and low thermal decomposition.

It was observed a weak influence of torrefaction heating rate under stability and thermal resistance, as well as under fixed carbon and volatile matter content.

Regarding in natura biomass, lower total mass loss for residues from coffee grain processing was observed when compared to Eucalyptus sawdust. This result was attributed to the differences on chemical and immediate molecular structure of the fuels.

The results suggest an improvement of hydrophobicity of carbonized and torrefied briquettes in relation to in natura, and the efficiency of the pretreatments performed.

\section{REFERENCES}

AMERICAN SOCIETY FOR TESTING MATERIALSASTM. D 1762- 84: standard test method for chemical analysis of wood charcoal. Philadelphia: ASTM International, 2007, 2p.

ARIAS, B. et al. Influence of torrefaction on the grindability and reactivity of woody biomass. Fuel Processing

Technology, Amsterdam, v.89, n.2, p.169-175, 2008. 
BARTKOWIAK, M.; ZAKRZEWSKI, R. Thermal degradation of lignins isolated from wood. Journal of Thermal Analysis and Calorimetry, Berlin, v.77, n.1, p. 295-304, 2004.

BRASIL. Ministério de Minas e Energia. Empresa de Pesquisa Energética. Balanço Energético Nacional 2011: ano base 2010. Rio de Janeiro, 2010, 266p.

BRAND, M. A. Energia de biomassa florestal. Rio de Janeiro: Interciência, 2010, 131 p.

BRIDGEMAN, T. G. et al. Torrefaction of reed canary grass, wheat straw and willow to enhance solid fuel qualities and combustion properties. Fuel, London, v.87, n.6, p.844-856, 2008.

CHEN, W. H. et al. Thermal pretreatment of wood (Lauan) block by torrefaction and its influence on the properties of the biomass. Energy, Amsterdam, v.36, n.5, p.3012-3021, 2011.

CHEN, W. H.; KUO, P. C. Torrefaction and co-torrefaction characterization of hemicellulose, cellulose and lignin as well as torrefaction of some basic constituents in biomass. Energy, Amsterdam, v.36, n.2, p 803-811, 2011.

COMPANHIANACIONALDEABASTECIMENTOCONAB. Avaliação da safra agrícola cafeeira 2011 - $1^{\text {a }}$ Estimativa - Janeiro/2012. Brasília: CONAB, 2012, 18p.

COUHERT, C.; SALVADOR, S.; COMMANDRÉ, J. M.

Impact of torrefaction on syngas production from wood. Fuel, London, v.88, n.11, p.2286-2290, 2009.

DENG J. et al. Pretreatment of agricultural residues for cogasiûcation via torrefaction. Journal of Analytical and Applied Pyrolysis, Amsterdam, v.86, n.2, p.331-337, 2009.

DEMIRBAS, A. Carbonization ranking of selected biomass for charcoal, liquid and gaseous products. Energy Conversion and Management, Amsterdam, v.42, n10, p.1229-1238, 2001.

DEMIRBAS, A. Effects of temperature and particle size on bio-char yield from pyrolysis of agricultural residues. Journal of Analytical and Applied Pyrolysis, Amsterdam, v.72, n.2, p.243-248, 2004.

FELFLI, F. F. et al. Wood briquette torrefaction. Energy for Sustainable Development,Amsterdam, v.9,n.3, p.19-22, 2005.
GANI, A.; NARUSE, I. Effect of cellulose and lignin content on pyrolysis and combustion characteristics for several types of biomass. Renewable Energy, Oxford, v.32, n.4, p.649-661, 2007.

\section{GRØNLI, M. G; VÁRHEGYI, G; DIBLASI,}

C.Thermogravimetric analysis and devolatilization kinetics of wood. Industrial Engineering Chemistry Research, Washington, v.41, n.17, p.4201-4208, 2002.

JOHN, M. J.; THOMAS, S. Biofibres and biocomposites. Carbohydrate Polymers, Amsterdam, v.71, n.3, p.343-64, 2008.

KIM, H. S. et al.Thermal properties of bio-flour-filled polyolefin composites with different compatibilizing agent type and content. Thermochimica Acta, Amsterdam, v.451, n.1-2, p.181-188, 2006.

KIM, U. J.; EOM, S.H.; WADA, M. Thermal decomposition of native cellulose: influence on crystallite size. Polymer Degradation and Stability, Amsterdam, v.95, n.5, p.778-781, 2010.

LIU, Z. T. et al. Study on the cationic modification and dyeing of ramie fiber. Cellulose, Berlin, v.14, n.4, p.337345, 2007.

MORÁN, J. I. et al. Extration of cellulose and preparation of nanocellulose from sisal fibers. Cellulose, Berlin, v.15, n.1, p.149-159, 2008.

PAULA, L. E. R. et al. Produção e avaliação de briquetes de resíduos lignocelulósicos. Pesquisa Florestal Brasileira, Colombo, v.31, n.66, p.103-112, 2011a.

PAULA, L. E. R. et al. Characterization of residues from plant biomass for use in energy generation. Cerne, Lavras, v.17, n.2, p.237-246, 2011 b.

POLETTO, M. et al. Thermal decomposition of wood: Influence of wood components and cellulose crystallite size. Bioresource Technology, Amsterdam, v.109, p.148 153, 2012.

PRINS, M. J.; PTASINSKI, K. J.; JANSSEN, F. J. J. G. Torrefaction of wood. Part 2. Analysis of products. Journal of Analytical and Applied Pyrolysis, Amsterdam, v.77, n.1, p.35-40, 2006. 
PROTÁSIO, T. P. et al. Compactação de biomassa vegetal visando à produção de biocombustíveis sólidos. Pesquisa Florestal Brasileira, Colombo, v.31, n.68, p.273-283, 2011a.

PROTÁSIO, T. P. et al. Torrefação e carbonização de briquetes de resíduos do processamento dos grãos de café. Revista Brasileira de Engenharia Agrícola e Ambiental, Campina Grande, v.16, n.11, p.1252-1258, 2012.

PROTÁSIO, T. P. et al. Relação entre o poder calorífico superior e os componentes elementares e minerais da biomassa vegetal. Pesquisa Florestal Brasileira, Colombo, v.31, n.66, p.122-133, 2011.

PROTÁSIO, T. P. et al. Brazilian lignocellulosic wastes for bioenergy production: characterization and comparison with fossil fuels. BioResources, Raleigh, v.8, n.1, p.1166-1185, 2013.

PROTÁSIO, T. P. et al. Correlações canônicas entre as características químicas e energéticas de resíduos lignocelulósicos. Cerne, Lavras, v.18, n.3, p 433-439, 2012b.

REPELLIN, V. et al. Modelling anhydrous weight loss of wood chips during torrefaction in a pilot kiln. Biomass and Bioenergy, Amsterdam, v.35, n.5, p.602-609, 2010.

SHAFIZADEH, F. Pyrolytic reactions and products of biomass. In: Fundamentals of Biomass
Thermochemical Conversion. London: Elsevier, 1985, p.183-217.

SHARMA, R. K. et al. Characterization of chars from pyrolysis of lignin. Fuel, London, v.83, n.11-12, p. 1469-2, 2004.

SHEBANI, A. N.; VAN REENEN, A. J.; MEINCKEN, M. The effect of wood extractives on the thermal stability of different wood species. Thermochimica Acta,

Amsterdam, v. 471, n.1-2, p. 43-50, 2008.

SHEN, D.K., GU, S. The mechanism for thermal decomposition of cellulose and its main products. Bioresource Technology, Amsterdam, v.100, n.24, p.6496-6504, 2009.

TRUGILHO, P. F.; SILVA, D. A. Influência da temperatura final de carbonização nas características físicas e químicas do carvão vegetal de jatobá (Himenea courbaril L.). Scientia Agraria, Curitiba, v.2, n.1-2, p.4553,2001 .

YAN, W. et al. Thermal pretreatment of lignocellulosic biomass. Environmental Progress \& Sustainable Energy, Hoboken, v.28, n.3, p. 435-440, 2009.

YANG, H. et al. In-depth investigation of biomass pyrolysis based on three major components: hemicellulose, cellulose and lignin. Energy Fuels, Washington, v.20, n.1, p.388-393, 2006. 